\title{
Manner adverbs and information structure: Evidence from the adverbial modification of verbs of creation ${ }^{1}$
}

\author{
Regine Eckardt
}

\begin{abstract}
The paper investigates the pragmatic effects of word order variation in German, specifically concerning the ordering of adverb and nominal arguments. The behaviour of verbs of creation in combination with adverbs and indefinite object NPs proves that the allegedly neutral word order NP Adverb Verb is not really presupposition free. I claim that indefinite object NPs to the left of manner adverbs receive a special kind of partitive reading which presupposes that the referent of NP is already contextually present before the reported event takes place. This will offer an explanation for the fact that in a sentence like Bob hat ein Flugzeug stabil konstruiert ('Bob has a plane solidly constructed') the object NP cannot receive an existential (indefinite) reading while the sentence Bob hat ein Flugzeug kunstvoll bemalt ('Bob has a plane artistically painted') seems to be able to refer to a previously unmentioned plane.
\end{abstract}

\section{Introduction}

The empirical observation on which this paper is based concerns a peculiar gap in the range of possible adverbial modifications in German. It is wellknown that manner adverbs in German can precede or follow the direct object. $^{2}$ Moreover, it apparently does not matter whether the object is a definite noun phrase or an indefinite noun phrase. The examples in (1) and (2) illustrate this fact: All sentences in (1) and (2) are equally well formed and the respective (a) and (b) variants seem to convey the same truth conditional contents.

(1) a. (daß) Hans vorsichtig eine Nuss öffnete (that) Hans carefully a nut opened

b. (daß) Hans eine Nuss vorsichtig öffnete (that) Hans a nut carefully opened 
(2) a. (daß) Hans langsam die Tür öffnete (that) Hans slowly the door opened

b. (daß) Hans die Tür langsam öffnete (that) Hans the door slowly opened

Furthermore, there is a class of result-oriented adverbs (see note 2) that specify the outcome of a certain event. These adverbs are restricted to positions after the direct object, and are acceptable with both indefinite and definite object NPs. This is exemplified in (3) to (5).

(3) *(daß) Hans schwer einen/den Wagen belud

(that) Hans heavily a/the carriage loaded

(4) (daß) Hans den Wagen schwer belud (that) Hans the carriage heavily loaded

(5) (daß) Hans einen Wagen schwer belud (that) Hans a carriage heavily loaded

Adverbs of both type can also be applied to verbs of creation and coming into existence. However, it turns out that if these verbs are combined with an indefinite object (as in (6)), then manner adverbs are restricted to the position preceding the object NP and, dramatically, result-oriented adverbs become unacceptable altogether, as shown by (10), (11).

Manner adverbs

(6) (daß) Hans geschickt eine Flöte schnitzte (that) Hans skilfully a flute carved

(7) (daß) Hans die Flöte geschickt schnitzte (that) Hans the flute skilfully carved

(8) *(daß) Hans eine Flöte geschickt schnitzte (that) Hans a flute skilfully carved

Result-oriented adverbs

(9) (daß) Hans den Pullover locker strickte (that) Hans the pullover loosely knitted

(10) *(daß) Hans einen Pullover locker strickte (that) Hans a pullover loosely knitted 


$$
\begin{aligned}
& \text { *(daß) Hans locker einen Pullover strickte } \\
& \text { (that) Hans loosely a pullover knitted }
\end{aligned}
$$

The basic question then is, why are sentences like (8), (10) and (11) bad while (7), (9) and (1b), (5) are acceptable?

I will start by reviewing some basic properties of manner and resultoriented adverbs (Section 2) and verbs of creation (Section 3). In Section 4, a wider and more systematic overview of the data will be given. In Sections 5 and 6, I will develop an account for the data in question that is based on the semantic and pragmatic properties of the sentences in question. It will be based on the assumption that object NPs that precede adverbs are topical in the sense of Jäger (1996b). While being topical is a natural state for a definite NP, Jäger showed that indefinite NPs in topical positions can only receive one of several non-straightforward interpretations that differ from the ordinary, presupposition-free purely existential interpretation of indefinites. I will demonstrate that topical indefinites will lead to almost context-neutral readings except with verbs of creation and coming into existence, where the temporal properties of topics and created objects are in conflict.

A brief summary and discussion of open questions will conclude the paper.

\section{Adverbs}

\subsection{Manner adverbs}

I will use the term "manner adverbs" to cover the class of adverbial modifiers that specify the manner in which a certain event was performed. This manner may come about due to a certain mood of the agent (wütend 'angrily', schüchtern 'shyly', fröhlich 'gaily'), due to his/her intentions (vorsichtig/aufmerksam 'cautiously'/'attentively', schlampig 'sloppily', freiwillig 'willingly', 'voluntarily', absichtlich 'intentionally'), be a mere matter of speed (schnell 'quickly', langsam 'slowly'), be a mixture of these (hastig 'hastily', ruhig 'calmly') or an indication of his/her dispositions and qualities (fachmännisch 'expertly', intelligent 'intelligently'). I will hence not distinguish between "subject-oriented" adverbs that are related to a property of an individual and purely event-related adverbs. ${ }^{3}$

Syntactically speaking, in German, these adverbs can occur in any position after the subject NP and before the minimal verbal domain. The possible distributions are illustrated in (12) to (17). 
(12) (daß) ein Kind wütend/schnell/fachmännisch einen Stock absägte (that) a child angrily/quickly/expertly a stick offsawed

(13) (daß) das Kind schüchtern dem Nikolaus eine Nuss überreichte (that) the child shyly to-the St.Claus a nut handed-over

(14) (daß) das Kind dem Nikolaus schüchtern eine Nuss überreichte (that) the child to-the St.Claus shyly a nut handed-over

(15) (daß) das Kind dem Nikolaus eine Nuss schüchtern überreichte (that) the child to-the St.Claus a nut shyly handed-over

(16) (daß) ein Kind einen Stock schnell/wütend/vorsichtig/... absägte (that) a child a stick quickly/angrily/carefully/... off-sawed

(17) *(daß) vorsichtig/wütend/... ein Kind einen Stock absägte (that) carefully/angrily/... a child a stick off-sawed

Some of the listed adverbs can precede the subject, but then they receive a different interpretation. Temporal adverbs in this position are usually interpreted not with respect to the speed or time of the event but rather they measure the time that elapsed between some previous reference time point and the beginning of the event:

(18) (daß) schnell ein Hase übers Feld hoppelte (that) quickly a hare over-the field hopped

$=$ the hare came soon after the reference time and may have hopped slowly

(19) (daß) ein Hase schnell übers Feld hoppelte (that) a hare quickly over-the field hopped $=$ it took the hare little time to cross the field

Some subject-oriented adverbs, typically those related to intentions, can receive an interpretation where it is not the subject but some background individual who shows the intention. An example is given in (20)/(21).

(20) (daß) ein Polizist absichtlich vor dem Eingang stand (that) a policeman intentionally in-front-of the entrance stood $=$ it was the policeman's intention to stand in front of the entrance 
(21) (daß) absichtlich ein Polizist vor dem Eingang stand (that) intentionally a policeman in-front-of the entrance stood $=$ it was someone else's intention to place a policeman in front of the entrance

Although it would be an attractive task to study the relation between presubjectival and post-subjectival readings in these cases, I will for now simply ignore the pre-subjectival case.

Moreover, the statement about possible distributions of manner adverbs is, for the time being, more an existential than a universal statement: For each manner adverb, there are at least some verbs plus arguments that allow the adverb between subject NP and object NP, and some verbs plus arguments that allow the adverb between or after the object NPs. There may be sentences where these possibilities are restricted; and there is a general, well-known tendency for definite NPs to precede the adverb. In Sections 5 and 6 , we will see that these effects are due to the different informational status of the object NP before and after the adverb. This diagnosis will explain the varying behaviour of definites, among other things, because some definites (the pope) are better out-of-the-blue than others (the man).

A notorious question in the literature on adverbs is the question of base positions vs. derived positions. The present overview of the data (which is very sparse in that respect, see the very detailed discussion in Frey and Pittner (1998), also Frey (this volume)) does not commit us to any answer with respect to this question. I will take up the question briefly in Section 7 without, however, attempting a final solution.

\subsection{Result-oriented adverbs}

Let me now turn to adverbs that specify the result of a certain event. Sentence (22) illustrates the case.

\section{(22) Miriam dressed elegantly.}

Sentence (22) has a reading that states that the result, rather than the process of dressing, is elegant - i.e. blouse and trousers match, are of a certain fashion etc. Intuitively, this kind of state of affairs differs from the manner reading of (22). In the manner reading, Miriam will have to make elegant moves in dressing no matter how shabby the attire will look afterwards. I will now recapitulate arguments why this intuitive difference must be mirrored by two distinct semantic variants of adverbs like elegantly. 
Taking the Davidsonian approach to manner adverbial semantics (as I will do), one might feel tempted to claim that these subtleties have no place in logical semantics proper. We could assume that elegantly in (22) above is simply a predicate of events $\lambda e$ elegant $(e)$ and it is an idiosyncratic case-tocase question what aspect of an event should give rise to calling it elegant. If you find this too coarse, remember that the same is common practice in the semantic representation of adjectives like red where most semanticians would also refrain from giving an exhaustive description as to when red $N$ means "the whole surface of $\mathrm{N}$ is red" (= red apples), "the entirity of $\mathrm{N}$ is red" (= red cherries; note that white cherries are white only inside), "the inside of $\mathrm{N}$ is red" (= red grapefruit) or "a specific part of $\mathrm{N}$ is red" (like in the red tap is for hot water).

However, this strategy will fail for result-oriented adverbs. We find adverbs that are ambiguous between a manner-oriented interpretation and a result-oriented interpretation. Elegantly in English (and elegant in German as well) is one of these. Sentence (22) can mean either that the resulting attire is elegant or that Miriam's movements and manner in dressing were elegant (in spite of a shabby result). This by itself would still not show the need for a finer semantic distinction of either reading: A red cherry can be one which is red inside and outside - in contrast to white cherries that are light red on the outside and whitish inside. Or it can be red on the outside no matter what the inside looks like, for instance if contrasted with green cherries that are still unripe. In both cases, we might claim that we master some conceptual core notion (of redness, of elegance) and can leave it to the context to decide which aspects or parts of an object or event should show the respective property.

Yet this simple solution will predict that all readings are available if and only if they get appropriate contextual support. Empirically, this is not the case. Sentence (23) exhibits only the manner interpretation of elegantly, and the German pair in (24a) and (24b) exhibits the same pattern.

(23) Miriam elegantly dressed. (= only manner reading)

(24) a. Sarah belud unsicher den Wagen mit Holz. Sarah loaded uncertainly the cart with wood $=$ Sarah loaded the cart with wood in a manner that showed that she was not certain whether or how this was to be done. (The load itself might have been stable.) 
b. Sarah belud den Wagen unsicher mit Holz.

Sarah loaded the cart uncertainly with wood reading 1: as in (a)

reading 2: Sarah loaded the cart with wood in such a way that the load was insecurely fixed on the cart afterwards. (Sarah herself was quite confident about her action.)

We observe that adverbs of result modification in German are restricted to a position directly preceding the verbal complex (in verb-final clauses) and following the direct object NP. Adverbs that are ambiguous between manner and result readings only show result modification in this position whereas purely result-oriented adverbs are confined to this position in general. This is exemplified in (24c), adapted from Geuder (2000):

\section{c. Sarah hat den Wagen schwer beladen. \\ Sarah has the cart heavily loaded \\ * Sarah hat schwer den Wagen beladen. \\ Sarah has heavily the cart loaded}

Geuder (2000) investigates the necessary semantic analysis of result modification in full detail. He argues that in order to maintain a coherent conceptual core of the respective adverbs (as well as their adjectival counterparts), it is appropriate to assume that the relevant events (of loading, dressing, decorating, etc. ) not only terminate in some unspecified "resultant state" but also produce a more specific concrete "resultant object". The resultant state might also be subject to temporal modification (as in Sarah loaded the cart with wood for 2 hours which implies that the wood remained on the cart for 2 hours). The resultant object is denoted by nouns like the load, the attire, or the decoration. If we assume that result-oriented adverbs predicate - in one way or another - over these resultant objects, we can nicely capture the fact that, unlike true manner modification, a sentence like (25) in its result-oriented reading is not paraphrased by (25a) (which corresponds to the true manner case) but by (25b).

(25) Olivia decorated the christmas tree elegantly.

a. The decorating of the christmas tree was conducted elegantly.

b. The decoration made the tree look elegant.

Olivia decorated the tree for three hours.

a. The decoration remained on the tree for three hours.

b. *The decoration of the tree took three hours. 
(26b) shows that the nominal decoration does not denote an object that would lend itself to temporal modification. Temporal modification of an abstract resultant state is possible as in (26) under the paraphrase (a), which offers further reason to distinguish between resultant state and resultant object. ${ }^{4}$ For a more detailed discussion of result-oriented adverbs, I refer the reader to Geuder (2000) and the sources quoted therein. In the remainder of the paper, we will draw on the following aspects of result-oriented adverbs:

(i) Result-oriented adverbs require a semantic analysis distinct from manner adverbs.

(ii) Result-oriented adverbs predicate over the resultant object of an event (and are hence restricted to verbs that denote events with some such object).

(iii) Result-oriented adverbs are restricted to positions to the right of the direct object NP ("directly before the verb" or before the verbal complex in terms of Frey and Pittner (1998)).

I will also use the terms resultative adverbs or result modifiers instead of "result-oriented adverbs".

\section{Verbs of creation and coming into existence}

So far, the result modifications that we have seen were predicated of results as performed on some given object (the woman dressed, the tree decorated, etc.). Verbs of creation and coming into existence - which I will abbreviate as verbs $s_{C C}$ - denote events which result in the creation of a new object rather than in the modification of a given one. The (real) object is usually denoted by the (grammatical) direct object in verbs of creation, and by the subject in verbs of coming into existence. In (27) to (33), I list some examples where the NP denoting the created object is given in boldface.

(27) a. Eine Beule entstand.

A bump emerged

b. Ein Stau entstand.

A traffic jam built-up

c. Ein Ausschlag bildete sich.

A rash formed

(28) Die Verhandlungen führten zu einem Vertrag.

The negotiations led to a contract 
(29) a. Andrea konstruierte eine Maschine. Andrea constructed a machine

b. Andrea komponierte ein Lied. Andrea composed a song

(30) a. Andrea hatte eine Idee. Andrea had an idea

b. Dem Andrea kam eine Idee. To-the Andrea came an idea

(31) Andrea schuf eine Statue. Andrea created a statue

(32) Andrea setzte eine Unterschrift unter den Vertrag. Andrea put a signature under the contract

(33) a. Andrea gab eine Antwort. Andrea gave an answer

b. Andrea stellte eine Frage. Andrea posed a question

It has been a matter of some debate what an appropriate semantic representation of verbs $s_{C C}$ should look like. Following Dowty (1979), Parsons (1990) and Zucchi (1999) pursued the idea that a verb like bauen 'build' should relate the creation event to an agent and an effected object in the same way as other transitive verbs like eat or love do. This strategy forces one to claim that even the smallest initial parts of the created object (e.g. the first brick of a future house) and the vague plan for such an object have to be in the extension of the respective nouns (e.g. house). In other words: Our ontology would be crowded with virtual and partial houses, machines, songs, novels, and so forth.

Von Stechow (2001) argues convincingly against such an approach. He pursues the idea that a sentence like (34) states that the agent does something to cause the proposition in (35) to become true in the future. Sentence (35) is not true while the event of creation is taking place.

(34) Sabrina baut eine Maschine.

Sabrina is-building a machine

(35) Es gibt eine Maschine, die von Sabrina gebaut wurde.

'There is a machine that was built by Sabrina.' 
He points out that the relation between (34) and (35) is similar to the case of intentionally opaque verbs like seek or owe. If the agent seeks a mushroom, for example, she undertakes something to make the proposition "agent finds mushroom" true. Examples (36)/(37) parallel (34)/(35).

(36) Sabrina sucht einen Pilz.

Sabrina is seeking a mushroom

(37) Es gibt einen Pilz, den Sabrina gefunden hat.

'There is a mushroom that Sabrina has found.'

In order to stress this similarity, von Stechow (2001) classifies verbs $s_{C C}$ as "temporally opaque verbs". He proposes to analyze a sentence like (38) along the paraphrase given in (39).

(38) Andrea baute eine Maschine.

Andrea built a machine

(39) Andrea is the agent of a building event e such that during the time of $\mathrm{e}$, the proposition "there is a machine $\mathrm{y}$ at time $\mathrm{t}$, and the occurrence of e causes y to exist throughout time t" turns from false to true.

This analysis will imply the existence of a machine of the appropriate kind after the event of creation has been completed, but without stating that any kind of machine-entity is existent before or while the event takes place. In particular, it is explicitly stated that no machine-created-in-e exists prior to the event in question. While I have to refer the reader to the original paper for the formal implementation of this idea, and the intricate arguments that show why this semantic treatment is superior to one based on virtual objects, I will adopt this view in the subsequent discussion.

Of course, an analysis of verbs $C$ in terms of temporal opacity does not exclude reference to plans in general. In (40a), the nouns one of the cakes and the cakes will obviously refer to the plans (recipes) in the cookbook, and $a$ cake in (40b) can be understood in that way as well.

(40) a. After having consulted my cookbook for some time, I baked one of the cakes.

b. After having consulted my cookbook, I decided to bake a cake (rather than waffles or biscuits).

In the following, I will sometimes carefully distinguish between reference to plans and reference to objects. While the option of reference to plans 
may be available in some cases, it is not, and need not be, in general. We find examples like (41) where any reference to previously existing intended objects or plans seems extremely unlikely.

(41) a. Hans hatte eine Idee.

'Hans had an idea.'

b. Andrea kritzelte einen Krakel aufs Papier.

'Andrea scratched a scribble onto the paper.'

c. Beate improvisierte ein Lied.

'Beate improvised a song.'

The NP eine Unterschrift ('a signature') in (42) also will refer to the created object, and not to a plan, under the most common reading of the sentence.

(42) Cecile setzte eine Unterschrift unter den Vertrag.

Cecile put a signature under the contract

In this case, that is not so much due to the fact that there were no signatureschemes: In fact there are. It is what is stored at your bank to make sure that the checks signed by yourself can be distinguished from those faked by others. Yet if we understood (42) such that the indefinite eine Unterschrift referred to such plans, the sentence would suggest that Cecile could choose amongst several such schemes when signing something. World knowledge will tell us that this is not the case - there is only one signature plan that is relevant for Cecile in all legal contexts.

\section{Possible combinations}

I will now review the result modification data for verbs of creation in detail. Bearing in mind the survey of possible adverbial modifications in Section 2, we will be better able to appreciate the crucial gap of impossible modifications.

We are concerned with (un)acceptable sentences that contain indefinite NPs. It is well-known that indefinites have a wide range of possible interpretations and that it is virtually always possible to understand any sentence with some one of these possible readings. Usually, two to three readings for indefinite NPs are distinguished in the literature. These are the following, exemplified for the noun Hund 'dog': 


\begin{tabular}{|l|l|l|l|}
\hline English & German & paraphrase & reading \\
\hline $\begin{array}{l}\text { dogs, } \\
\text { a dog }\end{array}$ & $\begin{array}{l}\text { Hunde } \\
\text { ein Hund }\end{array}$ & "every dog" & generic \\
\hline (one dog) & ein Hund & "one of several known dogs" & partitive \\
\hline $\begin{array}{l}\text { a dog } \\
\text { dogs }\end{array}$ & $\begin{array}{l}\text { ein Hund } \\
\text { Hunde }\end{array}$ & $\begin{array}{l}\text { "some, possibly first, dog(s) out } \\
\text { of the blue" }\end{array}$ & existential \\
\hline
\end{tabular}

Generic and partitive readings are available in the same positions and constructions and, in the case that an indefinite does not allow all three readings in some construction, we will always find either the existential reading, or both the generic and the partitive reading. The distribution of readings as well as possible driving forces for these interpretations have received wide attention in the nineties, starting with the work of Kratzer (1989/1995) and Diesing (1990, 1992), but also de Hoop (1992, 2000), Reinhart (2000), Ladusaw (1994), Eckardt (1996) and Jäger (1996b). The present work will mainly rely on the last source, offering further evidence in favour of the more differentiated four-way distinction advocated by Jäger. We will come back to this issue in Section 5. In the present section, we will still rely on the simpler distinction between generic, partitive and existential interpretation of indefinite NPs.

Let us start with examples with unambiguous manner adverbs that modify a verb of creation with definite/indefinite object and that are positioned to the right/left of the object NP. The full range of possible cases is given in (43) to (46).

(43) Beate baute aufgeregt einen Drachen. Beate built excitedly a kite

(44) Beate baute aufgeregt den Drachen. Beate built excitedly the kite

(45) \#Beate baute einen Drachen aufgeregt. Beate built a kite excitedly

(46) Beate baute den Drachen aufgeregt. Beate built the kite excitedly

Sentence (43) is most straightforward with the indefinite einen Drachen understood existentially, and conveys the evident proposition that Beate, excitedly, built a kite. Sentence (44) possibly requires a certain kind of context that allows the definite den Drachen to occur post-adverbially, but the effects are not very strong. The information conveyed is that Beate built the 
- somehow known - kite, excitedly. ${ }^{5}$ Sentence (46) means the same as (44) and they differ only in the kind of contexts in which one would rather use one or the other. Sentence (45) forces the indefinite NP to receive either a generic interpretation or a partitive interpretation.

(45') generic: Usually when Beate built a kite, she did it excitedly. (45") partitive: One of the kites she built, Beate built excitedly.

The existential interpretation of the indefinite is not accessible. In the remainder of the paper, I will use '\#' to mark this constellation while unstarred sentences with an indefinite mean "sentence acceptable with an existential interpretation of the indefinite". The following sentences illustrate the pattern further.

a. Daphne entwarfwütend einel die Hose. Daphne designed angrily a pair of/the trousers

b. Daphne entwarf die Hose wütend. Daphne designed the trousers angrily

c. \#Daphne entwarf eine Hose wütend. Daphne designed a (pair of) trousers angrily

(48) a. Euridike konstruierte vorsichtig ein/das gleichschenklige(s) Euridike constructed carefully an/ the isosceles Dreieck. triangle

b. Euridike konstruierte das gleichschenklige Dreieck vorsichtig. Euridike constructed the isosceles triangle carefully

c. \#Euridike konstruierte ein gleichschenkliges Dreieck vorsichtig. Euridike constructed an isosceles triangle carefully

Is there anything unusual about this pattern? If all verbs behaved like verbs of creation then the answer would clearly be "no". In that case, adverbials would simply be classed as indicator of the "VP boundary" in the sense of Diesing (1992). The most famous such indicator is the particle ja doch. The examples in (49) illustrate the general pattern: Indefinites to the right of $j a$ doch are preferably understood existentially, indefinites to the left are partitive or generic.

(49) a. (daß) Daphne eine Hose ja doch flickte (gen/part, no exist.) (that) Daphne a (pair of) trousers after all mended

b. (daß) Daphne ja doch eine Hose flickte (exist., gen/part possible) (that) Daphne indeed a (pair of) trousers mended 
Adverbs, however, do not behave like ja doch. For instance, they do not seem to mark a VP-boundary if they combine with verbs like flicken 'mend' or other verbs where an object is affected or destroyed. The following (b) examples allow for an existential reading of the indefinite object although it precedes the adverb.

(50) a. (daß) Daphne vorsichtig eine Hose flickte (exist. reading) (that) Daphne carefully a pair of trousers mended

b. (daß) Daphne eine Hose vorsichtig flickte (exist. reading) (that) Daphne a pair of trousers carefully mended

(51) a. (daß) Daphne wütend eine Hose zerriß (exist. reading) (that) Daphne angrily a pair of trousers tore

b. (daß) Daphne eine Hose wütend zerriß (exist. reading) (that) Daphne a pair of trousers angrily tore

If we derived the presence or absence of existential readings of indefinites solely from their position inside or outside VP (Diesing's mapping hypothesis) then we would make the unorthodox prediction that a manner adverb like carefully marks the VP boundary if combined with verbs of creation but it does not if combined with any other kind of eventive verb. While it would perhaps not be impossible to elaborate such a position, I will advocate a different line of explanation in Section 6.

Let us now turn to result-oriented adverbs. From Section 2.2. we know that they never occur to the left of an object NP. The picture for verbs of creation is consistent insofar as we find that result-oriented adverbs cannot modify a verb of creation plus an indefinite object NP. Sentences (52)-(53) illustrate this gap.

result: solide 'solidly'

a. Beate baute den Drachen solide.

Beate built the kite solidly

b. \#Beate baute einen Drachen solide.

Beate built a kite solidly

c. *Beate baute solide einen/den Drachen.

Beate built solidly a/the kite

result: ausdrucksvoll 'expressively ${ }^{6}$

a. (daß) Nick den Hund ausdrucksvoll knetete

(that) Nick the dog expressively modelled

b. \#(daß) Nick einen Hund ausdrucksvoll knetete

(that) Nick a dog expressively modelled 


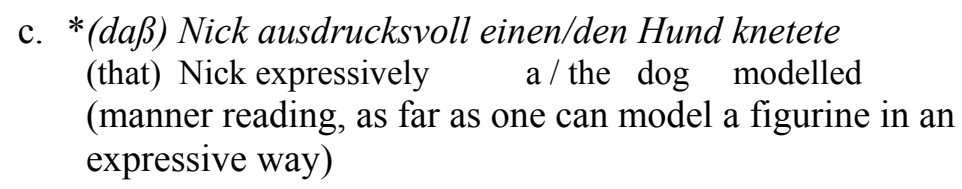

Once again, the indefinite NP before the result modifying adverb must receive a partitive or generic interpretation (which yields rather odd assertions). Some readers might find sentences like (52b) or (53b) acceptable in an existential sense if ein Drachen or ein Hund refer to plans (e.g. in a do-ityourself book). Similarly, a discourse like (54) is acceptable if we understand ein Rührkuchen to refer to the recipe in the book and not to the real cake that resulted from Auguste's baking (and we will see presently why the cookbook with all its recipes is necessary for the sentence to work):

(54) Auguste bekam Besuch von Hans, der allergisch auf Milch war. Zuerst hat sie lange im Kochbuch geblättert.

'Auguste expected the visit of Hans who was allergic to milk. First she read the cookbook for a long time.'

Dann hat sie einen Rührkuchen milchfrei gebacken.

Then has she a sponge cake milkfree baked

Two things will turn out to be crucial for (54) to be acceptable: Firstly, the plan for the sponge cake existed prior to the baking, and secondly, in the given context the sponge cake plan is one in a set of already implicitly mentioned plans for cakes in the cookbook.

While reference to plans is easily available for things to be built, knitted, kneaded, cooked or baked according to a given scheme, the respective NP will almost certainly refer to the created object when we report the new invention of the design or plan itself, like the design of a new costume or a new car. Consequently, the following examples are clearly "\#” according to my intuition, and do not allow for a rescue in terms of reference to plans like (54).

(55) a. (daß) Karl das Kostüm hauteng entwarf (that) Karl the costume tightly designed

b. \#(daß) Karl ein Kostüm hauteng entwarf (that) Karl a costume tightly designed

c. *(daß) Karl hauteng ein/das Kostüm entwarf

(that) Karl tightly a/the costume designed

d. (daß) Karl ein hautenges Kostüm entwarf

(that) Karl a tight costume designed 
(56) a. (daß) Opel das Auto sparsam konstruierte (that) Opel the car economically constructed

b. \#(daß) Opel ein Auto sparsam konstruierte (that) Opel a car economically constructed

c. *(daß) Opel sparsam ein/das Auto konstruierte (that) Opel economically a / the car constructed

d. (daß) Opel ein sparsames Auto konstruierte (that) Opel an economic car constructed

Similarly, (57) is resistant to a plan-denoting reading of eine Unterschrift.

(57) a. \#Auguste setzte eine Unterschrift vorsichtig unter den Vertrag. Auguste put a signature carefully under the contract

b. Auguste setzte die Unterschrift vorsichtig unter den Vertrag. Auguste put the signature carefully under the contract

c. Auguste setzte vorsichtig die/eine Unterschrift unter den Vertrag. Auguste put carefully the/a signature under the contract

Some verbs of creation do not find suitable result modifying adverbs, especially intransitive verbs. Yet they show very similar effects with suitable temporal adverbs. Examples (58) to (60) show the behaviour of the verb $\mathrm{CC}_{\mathrm{C}}$ eine Idee haben 'to have an idea' under the adverb plötzlich 'suddenly'. The (b) variants with the verb kaufen 'buy', which is not a verb ${ }_{\mathrm{CC}}$, are there to show that the peculiar effects are once more not the general behaviour of the adverb plötzlich but are restricted to the combination of plötzlich with $\operatorname{verbs}_{\mathrm{CC}}$.

(58) a. Sabine hat ganz plötzlich eine Idee gehabt.

Sabine has all suddenly an idea had

b. Sabine hat ganz plötzlich einen Hund gekauft.

Sabine has all suddenly a dog bought

(59) a. \#Sabine hat eine Idee ganz plötzlich gehabt.

Sabine has an idea all suddenly had

b. Sabine hat einen Hund ganz plötzlich gekauft.

Sabine has a dog all suddenly bought

(60) a. Sabine hat die Idee ganz plötzlich gehabt.

Sabine has the idea all suddenly had

b. Sabine hat den Hund ganz plötzlich gekauft.

Sabine has the dog all suddenly bought 
Sentence (59b) shows that the temporal adverbial plötzlich cannot be the benchmark between existential and non-existential indefinites in general, as the sentence can well report that Sabine bought a dog (suddenly) without any other dogs being mentioned in the context (which would be the partitive reading). The intransitive case is illustrated in (61).

(61) a. \#(daß) ein Stau ganz plötzlich entstand (that) a traffic-jam all suddenly built up

b. (daß) ganz plötzlich ein Stau entstand (that) all suddenly a traffic-jam built up

c. (daß) der Stau ganz plötzlich entstand (that) the traffic-jam all suddenly built up

Example (62) offers a reflexive case, this time with a suitable resultoriented adverb. (We will ignore the marginal reading of (62c) "curiously, a crystal built up". This evaluative reading of "curiously" in English must be translated to the German kurioserweise.)

(62) a. (daß) der Kristall sich kurios ausbildete (that) the crystal itself curiously built up

b. \#(daß) ein Kristall sich kurios ausbildete (that) a crystal itself curiously built up

c. *(daß) sich kurios ein/der Kristall ausbildete (that) itself curiously a / the crystal built up

Let me finally briefly summarize the range of data we have seen.

- If a transitive $v e r b_{C C}$ is combined with a manner adverb, the adverb has to precede any existential indefinite object NP. Otherwise, the indefinite will have to be understood partitively or generically.

- Hence, no transitive $v e r b_{C C}$ can be combined with a result-oriented adverb and an indefinite object NP in existential reading.

- Some cases can be rescued if the indefinite NP is interpreted as referring to a plan rather than an object. (The specific contexts that license these readings will be reviewed presently.)

- If an intransitive verb $b_{C C}$ is combined with an adverb, the adverb has to precede any existential indefinite subject NP.

- Conjecture: if there were result-oriented adverbs for such verbs, they could not be combined with an indefinite subject NP.

- None of the adverbs involved shows similar effects with event-denoting verbs other than those of creation and coming into existence. 
Which leaves us with the puzzling question: Why does the combination of adverbs and verbs ${ }_{C C}$ differ from adverbial modification of other verbs?

\section{Subtle topics}

Jäger (1996b) proposes an extension of classical dynamic semantic frameworks in order to capture various ways of "being topical" or "definite" in a unified way. It would be beyond the limits and aims of the present paper to recapitulate Jäger's full formal system, but conveniently he proposed a terminology inspired by Kamp's Discourse Representation Theory. In this section, I will recapitulate some of Jäger's core ideas. ${ }^{7}$

Most importantly, Jäger distinguishes between discourse referents $d_{1}, d_{2}$, $\ldots$ and "Understood Entities" $p_{i}, p_{j}, \ldots$ (Jäger calls these "pegs" but Groenendijk and Stokhof's pegs have found quite different tasks to serve and I hence propose this terminology to stress the originality of Jäger's notion). Every discourse referent automatically gives rise to an understood entity, but we may have more understood entities than discourse referents. (Discourse referents also may "die" when becoming unsalient.) Discourse referents, as in Discourse Representation Theory, keep the record of individuals that have been explicitly mentioned in a discourse. They, and only they, are accessible antecedents for anaphoric (singular) pronouns.

Understood Entities, in contrast, are such individuals or objects that can be inferred by the intelligent hearer without necessarily being mentioned. The boldface definites in examples (63) and (64) pick up such Understood Entities while the (unacceptable) pronouns show that they do not have the status of discourse referents.

(63) Sue was stabbed. The criminal / *He had worn a black leather jacket.

(64) Joe bought a new car. The horn / *It plays the beginning of "Clementine".

Yet we can use definites that do not even refer to such Understood Entities. Notorious examples are the sun or the pope which can enter any discourse at any point and refer to their referents much in the way of proper names. Jäger calls these definites "referential" and claims that they, and only they

(a) can occur in thetic sentences

(b) must have a unique referent out there in the world. 
Definites that refer to Understood Entities, on the other hand, have topical status $^{8}$ and need only be unique among the set of Understood Entities, not in the world: Sentence (63), for instance, does not rely on the fact that there is but one criminal in the world. The use of Understood Entities allows Jäger to propose and model the following distinction: ${ }^{9}$

\begin{tabular}{|l|l|l|}
\hline Kind of NP & Status & Reference \\
\hline pronoun & topical & $\begin{array}{l}\text { to discourse referent, need not } \\
\text { be unique }\end{array}$ \\
\hline definite NP & $\begin{array}{l}\text { topical } \\
\text { (in categorical judgements) }\end{array}$ & $\begin{array}{l}\text { to Understood Entity, must be } \\
\text { unique among the UEs }\end{array}$ \\
\hline definite NP & $\begin{array}{l}\text { non-topical } \\
\text { (in thetic judgements) }\end{array}$ & $\begin{array}{l}\text { introduces new DR and UE, } \\
\text { must be unique in the world }\end{array}$ \\
\hline
\end{tabular}

Interestingly, Jäger extends his approach to the discussion of topical and non-topical indefinites, and he offers a truer picture of the full range of readings of indefinite NPs in all kinds of constructions than can be found elsewhere in the literature. He takes subjects of individual-level predicates to be the test case of a topical $\mathrm{NP}^{10}$ and diagnoses the following range of readings for German topical indefinite NPs in that position (following common practice, I will use be blue eyed, be intelligent as prototype instances of individual-level predicates). The words in boldface are meant to bear main stress.

(65) generic reading:

a. Ein Schwede ist blauäugig.

A Swede is blue-eyed

b. Schweden sind blauäugig.

Swedes are blue-eyed

(66) partitive reading:

a. Ein Schwede ist blaü̈ugig.

One Swede is blue-eyed

b. Zwei Schweden sind blauäugig.

Two Swedes are blue-eyed

c. Einige Schweden sind blauäugig.

Some Swedes are blue-eyed

d. Kein Schwede ist blauäugig.

No Swede is blue-eyed 
in-group reading: Being one of a known set of people

(Die ganze Halle stand voller Menschen aller Nationen mit den untypischsten Augenfarben.)

('The whole hall was filled with people of all nations with the most untypical eye colours.')

a. Ein Schwede war schwarzäugig.

A Swede was black-eyed

b. Ein Schwarzafrikaner war blaü̈ugig.

A black African was blue-eyed

$\cdots$

The three readings differ characteristically in their intonation pattern. Sentence (65) reports something about the typical Swede. The subject is left unstressed. It is not entirely clear to what extent such sentences suggest that one has been talking about Swedes all along, but there is general agreement that the referent of indefinites in a generic interpretation can be "old" material - if only by the fact that "the Swede" as a kind is obviously part of our shared world knowledge.

If the noun is left unstressed but the determiner is stressed, as in (66), we will understand the partitive (or "truly quantificational") interpretation of the NPs. The sentences in (66) presuppose a set of known Ns (Swedes in our example), say something about some of these and strongly suggest that there are still other Ns or at least that there might be.

We have already seen the last two readings in Section 4. The interpretation of the indefinite in (67), however, has received little attention in languages like German and English. Turkish marks this reading more pointedly, and it has hence evoked more attention in the literature, e.g. in Enç (1991). Moreover, it has recently been studied in language acquisition under the label "source-set reading", cf. Krämer (2000). At first glance, the reading may seem like a purely existential reading. The sentence Ein Schwede war schwarzäugig in the context of (67) does not presuppose the existence of more Swedes, and neither does the sentence require a context where Swede Discourse Referents or Understood Entities are available. Nevertheless, it needs a context in which a set of persons is explicitly or implicitly known, and the Swede is one of these. In other words, the interpretations in (67) are not available in a deserted discourse universe. I will call this interpretation of ein $N$ the in-group interpretation. ${ }^{11}$

The sentences in (67) bear a second stress on the adjective. This brings them close to the hat contour pattern investigated by Büring, and in fact Büring's and Jäger's data overlap without an explicit uniform treatment of all cases being given in either work. In particular, note that (67) would be a puzzling case for Büring $(1996,1997)$, who treats topic and focus semantics 
as something in addition to an ordinary semantic interpretation of sentences: Common semantic wisdom would have it that in a sentence like $A$ Swede is blue-eyed, the indefinite NP cannot receive a non-partitive and non-generic interpretation. Such a reading is not available out-of-the-blue but rather requires an appropriate context. In Büring's (as well as Rooth's, Krifka's, Jacobs', von Stechow's) sense, focussing and topic-marking are devices that one can apply to a sentence, or one can leave the sentence as it is and interpret it "ordinarily". In the cases above (as well as the adverbial examples we will presently come to), there is no "ordinary" interpretation of the sentence prior to the indicated topic/non-topic distinction. In other words, a sentence like Ein BÄCKer war unheimlich INTELLIGENT, when uttered after a TV quiz show, can get an in-group interpretation if and only if the appropriate topic structure is applied. The reading does not exist prior to topicalization, unless we claimed that the sentence has readings that exist (namely one with an existential interpretation of the subject indefinite) but that somehow never surface in neutral contexts.

While Jäger thus offers a truer picture of the effects of topicality in his examples, he has nothing to say with respect to the question of why and how topical material associates (and even has to associate) with focus, and how the overall structure relates to a topical question in the discourse at that point. In the appendix, I will attempt to shed further light on the various advantages and disadvantages of Jäger's and Büring's accounts and propose a synthesis of their ideas. In the main body of the paper, I will restrict my attention to the empirical side of topical indefinite NPs.

Summarizing, in German, we find the following interpretations of indefinite NPs, depending on whether or not they are topical, and on the internal focal structure of the topical phrase. I use the noun Kind 'child' as an example.

\begin{tabular}{|l|l|l|}
\hline Indefinite + Intonation & Status & Interpretation \\
\hline $\begin{array}{l}\text { ein Kind } \\
\text { (accent depending on posi- } \\
\text { tion in sentence) }\end{array}$ & $\begin{array}{l}\text { non-topical ("rhe- } \\
\text { matic") }\end{array}$ & $\begin{array}{l}\text { existential: there is a new } x \\
\text { that is CHILD, } \\
x \text { is a new discourse referent, } \\
x \text { does not equal an old UE, } \\
\text { and it is not part of an old UE. }\end{array}$ \\
\hline $\begin{array}{l}\text { Ex.: Es stand ein Kind vor der Tür. ('There was a child standing in front of the } \\
\text { door.') }\end{array}$ & $\begin{array}{l}\text { generic: all children, } \\
\text { somewhat open status with } \\
\text { respect to UEs. }\end{array}$ \\
\hline ein Kind & topical \\
\hline
\end{tabular}




\begin{tabular}{|c|c|c|}
\hline ein Kind & topical & $\begin{array}{l}\text { partitive: one of a set } P \text { of } \\
\text { CHILDren, } \\
\text { set } P \text { must be an old UE. }\end{array}$ \\
\hline \multicolumn{3}{|c|}{$\begin{array}{l}\text { Ex.: Es spielten Kinder draußen. Ein Kind begann zu weinen. ('There were } \\
\text { children playing outside. One of the children started crying.') }\end{array}$} \\
\hline ein Kind & topical & $\begin{array}{l}\text { in-group: } x \text { is a CHILD, } \\
x \text { is new as a DR and UE, } \\
x \text { is part of an old UE. } \\
\text { The old UE was introduced as } \\
\text { a set of } Q \text { 's, CHILD } \subseteq Q .\end{array}$ \\
\hline \multicolumn{3}{|c|}{$\begin{array}{l}\text { Ex.: Es saßen einige Patienten im Wartezimmer. Ein Kind hatte Schnupfen. } \\
\text { ('There were some patients sitting in the waiting room. A child hat a cold.') } \\
\text { *Es saßen einige Kinder im Wartezimmer. Ein Kind hatte Schnupfen. } \\
\text { ('*There were some children sitting in the waiting room. A child had a cold.') }\end{array}$} \\
\hline \multicolumn{3}{|c|}{$\begin{array}{l}\text { Es saßen einige Kinder im Wartezimmer. Ein Kind hatte Schnupfen. } \\
\text { ('There were some children sitting in the waiting room. One child had a cold.') } \\
\text { Das Wartezimmer war noch völlig leer. *Ein Kind hatte Schnupfen / Ein Kind } \\
\text { kam herein. } \\
\text { ('The waiting room was still empty. *A child had a cold. / A child entered the } \\
\text { room.') }\end{array}$} \\
\hline
\end{tabular}

In the appendix, I will briefly (and without further justification) outline how these readings can be derived in a compositional framework. For now, I will take this refined notion of the nature of topical indefinites as a starting point for another look at possible readings (and intonations) of indefinite NPs cooccurring with manner and result adverbs.

\section{Pre-adverbial indefinites - accommodating an environment}

It is a well-known fact about German intonation that sentences with a preadverbial object NP - in particular if it is an indefinite NP - have to bear several accents in order to avoid any readings with narrow focus. I will use (68) to demonstrate the case. (68a) bears a "neutral" stress pattern while (68b, c, d) must be understood with narrow focus on Huhn, vorsichtig, and vorsichtig gestreichelt, respectively. The reader is free to add more patterns with one or two accents which will always result in narrow focus.

(68) Alicia hat ein Huhn vorsichtig gestreichelt.

Alicia has a chicken carefully stroked

a. Alicia hat ein Huhn vorsichtig gestreichelt.

b. Alicia hat ein Huhn vorsichtig gestreichelt. 
c. Alicia hat ein Huhn vorsichtig gestreichelt.
d. Alicia hat ein Huhn vorsichtig gestreichelt.

This contrasts sharply with the inverse word order in (69) which shows the neutral stress pattern of this type of sentence. Superficially speaking, one will realize that for (69) one accent is sufficient while (68a) requires three.

(69) Alicia hat vorsichtig ein Huhn gestreichelt.

Alicia has carefully a chicken stroked

A very similar effect for English sentences with manner adverbs has been described in Gussenhoven (1983) who provides an accent assignment mechanism for either case, yet without much discussion of any structural or pragmatic reasons for this effect.

Jacobs $(1992,1993)$ describes accent-assignment in German as a mechanism that has to rely on a variety of conspiring factors rather than syntactic structure alone - which many prominent prosodic theories take as their starting point. In Jacobs' terms, a constituent $\alpha$ can integrate into another constituent $\beta$ under certain circumstances. The constituents can be tied together by "integration", in which case this "integrated" domain can receive one single accent. Several factors support integration. For example, verbs and objects can only integrate if the thematic relation of the object is appropriate (PATIENT-like rather than EXPERIENCER or STIMULUS). They can only integrate if they are adjacent; and adverbs generally inhibit integration and do not integrate themselves.

Sentences such as (68a) can be used as out-of-the-blue utterances and are therefore commonly assumed to be neutral with respect to the preceding context. I think that this assumption is wrong. Instead, I claim that object noun phrases that stand to the left of manner and result adverbs are topical in the sense of Jäger (1996b). Their status is driven not by the intonation as such but by their syntactic position which will automatically impose certain (yet unobtrusive) contextual restrictions on the sentences in question. However, the speaker still has the choice of marking part of the topical material as new (in focus) by using one of several possible accent patterns. The examples in (70) show that we find exactly the three possible interpretations of topical indefinite NPs that were listed in Section 5:

(70) a. generic: Alicia hat ein Huhn vorsichtig gestreichelt / vorsichtig gestreichelt / vorsichtig gestreichelt.

b. partitive: Alicia hat ein Huhn vorsichtig gestreichelt.

c. in-group: Alicia hat ein Huhn vorsichtig gestreichelt. 
In sentence (70a), I list all possible accent patterns with unaccented object NP. The object NP is always understood generically, i.e. referring to what Alicia does to chickens in general. However, the overall focus structure of (70a) still drives the generic statement in question (an effect that was described in Rooth (1995)). The different variants in (70a) mean that "what Alicia generally did to chickens was, to stroke them carefully" - "the way in which Alicia generally strokes chickens was: carefully" and "what Alicia generally did to chickens in a careful manner was: to stroke them". ${ }^{12}$

In (70b) we find the partitive interpretation of the topical indefinite NP that is triggered by the accent on the numeral. The sentence will require a previously mentioned set of chickens in order to receive an interpretation. Once more, we need a second - focus - accent later in the sentence. I give the (most natural) case with focussed adverb. (70b) means: One of the chickens that were stroked by Alicia was stroked carefully. (The readings have already been described in Geilfuß (1992), Geilfuß-Wolfgang (1996) and Eckardt (1999) but the eventual picture which I will propose will set them in a different light.)

The sentence in (70c) has been held as the "neutral" topic-free variant of sentence (68) so far. If I am right, however, and the indefinite ein Huhn is generally topical, then ein Huhn should exhibit the in-group reading in (70c) $(=68 \mathrm{a})$. I will now argue for the following two points:

(a) The contextual restrictions that are set by the in-group reading of (70c) are minimal. They require the hearer to accommodate an interest in the question What did Alicia do in the situation that the speaker wants to describe? This minimal interest will be supplied at least by politeness and hence has never been diagnosed as a "presupposition" of the respective sentences.

(b) The contextual restrictions still bear enough information to rule out verbs of creation. Verbs of creation are hence the test case which shows that the pattern is not really presupposition-free.

Addressing (a), let us have a closer look at the putative in-group reading of (70c).

- The indefinite will introduce a new discourse referent $\mathrm{x}$ that has to be part of an acquainted group $\mathrm{P}$ of individuals which have to be known not as being a chicken but as being an animal.

- The construction interacts with the focus structure of the material that follows. The non-topical background will tell us what Alicia did to the animals, and the focus will tell us how Alicia acted on one particular chicken among these animals. 
The following discourse offers an example in which all these prerequisites for $(70 \mathrm{c})$ are explicitly present.

(71) Alicia ging in den Stall und hat alle Tiere begrüßt.

'Alicia went to the stable and greeted all animals.'

Sie hat ein Huhn vorsichtig gestreichelt, (... sie hat eine Kuh

She has a chicken carefully stroked (... she has a cow

zärtlich gestupst, und sie hat ein Pferd liebevoll gefüttert.)

tenderly pushed and she has a horse lovingly fed)

The focussed verbal complexes vorsichtig gestreichelt 'carefully stroked', zärtlich gestupst 'tenderly pushed' and liebevoll gefüttert 'lovingly fed' are all instances of the alternatives that were introduced by begrü $\beta t$ 'greeted' in the first sentence.

If no such explicit context is given, then the hearer will have to accommodate one, and at best a fairly minimal and plausible one. A minimal assumption about the set of Ps is this: "The speaker wants to tell me about Alicia in a certain situation. He mentions a chicken $x$ which is part of some known set $P$. Let me assume that the speaker wants to tell me how Alicia acted on $P$, where $P$ is the set of visible objects in her environment. It is virtually always safe to assume that Alicia has such an environment."

\section{IGA: In-group accommodation:}

Accommodation 1: $\mathrm{P}=\{$ the visible things around Alicia $\}$

Accommodation 2: Focus alternatives under debate

$\mathrm{FA}=\{$ what did Alicia do to the things around her $\}$

These two accommodations can also simply be described as "the speaker wants to tell me what Alicia did to (some of) the things around her". And it is easy to see that this conversational minimum might be mistaken for the "neutral context".

Interestingly, subtle stylistic differences between sentences like (72) and (73) lend support to my diagnosis. Intuitively speaking, sentence (72) starts with Alicia "on a bare plane", so to speak, and after it has been computed we do not visualize more about the scene than Alicia in the emptiness, eating an apple. Sentence (73), in contrast, seems to evoke a scene where Alicia is "somewhere" amidst things surrounding her: In front of a bowl of fruit - or on a meadow below an apple tree - or simply at a table littered with all kinds of junk. 
(72) Alicia hat vorsichtig einen Apfel gegessen. Alicia has carefully an apple eaten

(73) Alicia hat einen Apfel vorsichtig gegessen.

Alicia has an apple carefully eaten

Although I am convinced that these effects exist, one would clearly not want to build an entire semantic analysis of (72) and (73) on them. On one hand, one might object that even the contents of sentences like (72) are usually not understood to take place in the empty space, and once we start to imagine a suitable environment for (72) it will fit (73) as well and vice versa. On the other hand, even those who share my judgement about the intuitively felt differences might conjecture that these differences are not due to the formal interpretation of prosodic patterns but rather are a side effect of a style of narration (say, one that is rhythmic, slow, contemplative, allows for accents and breaks, and hence signals the speaker's intention to colourfully describe a scene), while the unpretentious (72) is used to convey pure information rather than to narrate.

Matters change once we use sentences with verbs of creation. Let us turn to example (74) with the - corresponding - accents, as in (74a). If our story so far is right then (74a) should evoke the accommodations in (75). And (76) elucidates why these accommodations will at once contradict the content conveyed by (74).

Alicia hat eine Taschenlampe vorsichtig konstruiert. Alicia has a torch carefully constructed a. Alicia hat eine Taschenlampe vorsichtig konstruiert.

(75) In-group reading of eine Taschenlampe with standard accommodation of set P: There was a torch among the visible things surrounding Alicia.

Focus: What did she do to that torch? She constructed it carefully.

(76) The torch created by Alicia only came into existence after the event of creating it. "Creating something" is not an act that you can perform on the visible things around you.

Hence, verbs of creation offer a case where the required accommodations fail to make sense and yield no sensible out-of-the-blue reading of the respective sentences. ${ }^{13}$

We will now turn to those variants of adverbial modification of verbs $s_{C C}$ that do make sense and will discuss why. It will turn out that IGA is so prominent an accommodation in out-of-the-blue contexts that one will 
rather class a sentence as ungrammatical than turn from this very loose contextual restriction to a stronger one. The discourse in (77) offers a suitable context for the last sentence which is, hence, acceptable.

(77) Es standen überall selbstgemachte Gefäße herum.

'There was a lot of home-made pottery standing around.'

Alicia hatte eine Schüssel sorgfältig getöpfert, aber alles andere Alicia had a bowl carefully modelled but everything else sah ziemlich schief aus.

looked fairly awkward

The presupposed set $\mathrm{P}$ is the set of home-made pots, and the salient alternatives are all well-formed answers to Which pot did Alicia make how? The sentence is straightforward then, but the context is evidently more than zero.

Another possibility to turn IGA into a presupposition that coheres with the content of the sentence is to interpret the NP as a plan-referring one. Consider the discourse in (78).

(78) Robert schmökerte lange in der Handarbeitszeitschrift herum. Zuerst fand er die Vorschläge alle ziemlich dröge, aber dann hatte er die geniale Idee:

'Robert read in the handcraft journal for a good while. At first, he found all the suggestions fairly dull, but then he had an ingenious idea:'

Er hat einen Pullover mit einer superdicken Häkelnadel

He has a pullover with an extremely thick crocheting needle

gehäkelt

crocheted

(und dann sah das Modell völlig hip aus).

('and the result looked really hip')

As häkeln 'to crochet' is a verb of creation and the PP mit einer superdicken Häkelnadel 'with an extremely thick crocheting needle' cannot be a noun modifier (*Pullover mit einer superdicken Häkelnadel) we would expect the sentence to be bad. However, here the NP ein Pullover can refer to the garment proposed in the journal. The instruction for the pullover clearly exists prior to the event of crocheting, and the set $\mathrm{P}$ of instructions for garments of which the pullover is an element is clearly an understood object in the given context. And finally, due to the fact that such journals usually offer instructions for knitting, crocheting and perhaps sewing, we even find reasonable alternative ways of construction that can serve as focus alternatives. This matches with the fact that the sentence in (78) allows smoothly for a focus on the whole verbal complex mit einer superdicken Häkelnadel häkeln. The 
sentence in (77) contradicts this focus structure, and there seems to be no reasonable way to think of alternative ways of creating pottery. This effect is even more dramatically visible for rather neutral verbs of creation like bauen 'build', entwerfen 'design', konstruieren 'construct'.

All the effects listed so far can hence be explained if we assume that the object NP to the left of an adverb (of manner, of result) in German is topical, and verbs of creation and verbs of affective actions differ only insofar as one and the same information structure (topical indefinite object in an ingroup reading) can be met by an extremely low-effort accommodation in one case but needs contexts that look very restricted in the other case.

Definite object NPs in topical position are unproblematic. If they are completely unaccented, then they can refer to a previously mentioned entity. We can leave it to the logical and linguistic competence of the speaker to ensure that the respective discourse referent or understood object was introduced in a coherent manner.

(79) Paulina mußte in der Schule ein Schiffchen und eine Taschenlampe konstruieren.

'Paulina had to construct a ship and a torch at school.'

Sie hat die Taschenlampe sparsam konstruiert,

she has the torch economically constructed

und kriegte auch eine gute Note dafür.

and got also a good grade for it

We can also get an in-group reading if the definite NP is not anaphoric but licensed as an understood object as in examples $(63) /(64)$ in the previous section.

(80) Paulina mußte ein Schiffchen bauen.

'Paulina had to build a ship.'

Sie hat die Steuerung sehr ökonomisch konstruiert

she has the steering very economically constructed

(und bekam dann einen Preis dafür).

('and got a prize for it')

The explanation sketched here can also help us to spot other cases where topical indefinite NPs may be problematic. If we separate subjects of verbs like entstehen from the verb by adverbial modification, they become topical and the same effects arise as in (74). 
(81) \#(daß) ein Stau rasch entstand

(that) a traffic-jam quickly built up

presupposed: The jam is one of a set of known objects on the scene.

focussing: What did happen to this traffic-jam?

Assertion: It built up.

Contradiction: Existing objects cannot build up.

Once more, the indefinite in non-topical position is as acceptable as a definite in topical position:

(82) (daß) rasch ein Stau entstand (that) quickly a traffic-jam built up (daß) der Stau rasch entstand (that) the traffic-jam quickly built up

Interestingly, we find parallel behaviour for verbs that were already equated with verbs of creation by von Stechow (2001). Opaque verbs like suchen 'seek' and schulden 'owe' can refer to virtual objects which need not exist anywhere near the events or states reported in the sentence. Adverbs once more require the NP to their left to be topical and lead to IGA to allow for an in-group reading of indefinites in out-of-the-blue contexts. Sentence (83) can only be understood to refer to a given mushroom that is already present somewhere on the scene. It implies the existence of a mushroom, while sentence (84) does not.

(83) Hans hat einen Pilz fieberhaft gesucht.

Hans has a mushroom feverishly sought

presupposed: There is a mushroom somewhere at the scene of the event.

focussing: What did Hans do to that mushroom?

Assertion: He was seeking it.

Consequence: There exists a mushroom that Hans seeks.

(84) Hans hat fieberhaft einen Pilz gesucht.

Hans has feverishly a mushroom sought

no mushrooms are implied to exist

Finally, note that in-group readings do not always literally require the physical presence of the group at stake. Verbs like loben 'praise' allow for objects that are remote or even dead. The wider restriction here seems to be that they must exist independently of the event reported. 
(85) Juliane hat Goethe / einen Dichter wortreich gelobt. Juliane has Goethe/ a poet eloquently praised

Neither Goethe nor the referent of einen Dichter have to be part of a group of physically present persons. In the case of verbs of saying and thinking, it seems to suffice that these persons existed prior to the event (here: of praising). Nevertheless, this does not mean that no restrictions hold: Sentence (86) is again bad because the poet heralded ('prophesied') cannot be imagined out-of-the-blue as one of a number of somehow given artists. (87) shows the admissible variant.

(86) *Marcel Reich-Ranicki hat ein neues Genie wortreich prophezeit. Marcel Reich-Ranicki has a new genius eloquently heralded

(87) Marcel Reich-Ranicki hat wortreich ein neues Genie prophezeit. Marcel Reich-Ranicki has eloquently a new genius heralded

Let me finally summarize the core findings of this section.

- Object NPs in the position to the left of a manner or result adverb are topical in German. Subject NPs of verbs of coming into existence in the position to the left of manner (and temporal) adverbs are topical in German.

- Matching the results of Jäger (1996a, b), we found that topical indefinite NPs can be interpreted generically, partitively or in the in-group reading.

- All three readings associate with focus later in the sentence.

- The in-group reading with verbs of affective action requires contexts which are very often tantamount to saying "we assume a common interest in what the subject did to some thing in his/her environment". These sentences have previously been mistaken as out-of-the-blue sentences without pragmatic side effects.

- The in-group reading with temporally or modally opaque verbs does not allow for such contexts. The sentences are acceptable in restricted contexts but have never been mistaken to be out-of-the-blue sentences.

These are also the main results of the present paper. In the final section, I will relate these findings to other positions in the literature. 


\section{On word order}

There is an ongoing debate in the investigation of the grammar of adverbs as to whether adverbs have syntactic base positions. I will not be able to cover all relevant opinions in this section but want to relate my findings to two positions that are potentially affected.

There is a substantial body of literature that in synopsis suggests a strong correlation between "moved NPs" and "topical NPs" in German. The discussion that I will refer to was originated by the work of Kratzer (1989/1995) and specifically Diesing (1990, 1992) who demonstrated for German that indefinite NPs outside VP must be interpreted generically or partitively ${ }^{14}$ while those that can receive an existential reading were diagnosed to be situated in their base position (inside VP). Ladusaw (1994) was the first to propose that the true effect of these movements (in German) was to turn non-topical material into topical material. As the original function of indefinite NPs is to introduce new discourse referents into the discourse universe, Ladusaw argues, they have to undergo specific reinterpretations if they are topical. By this explanation, the distinction between existential and generic indefinites (and related issues like the well-known individuallevel/stage-level distinction) is linked to deeper semantic-pragmatic mechanisms. This is to be preferred to the somewhat ad-hoc representational semantic interpretation mechanism proposed by Diesing.

Jäger (1996a, b) elaborated Ladusaw's proposal and formulated an explicit synthesis between Diesing's and Ladusaw's findings, equating NPs that are scrambled out of VP, NPs that are topical, and NPs that receive generic, partitive or (Jäger 1996a, b) in-group readings.

Eckardt $(1996,1998)$ demonstrates that there is a coherent correlation between indefinite NPs that are covered by the focus domain created by "neutral" sentence accent and indefinite NPs that are interpreted existentially. Viewed from this angle, it turns out that the movements (out of VP) as diagnosed by Diesing can equally well be seen as movements out of the focus domain of the "neutral" sentence accent. These observations finally fit in coherently with the classical findings of Höhle (1982) that, in German, scrambling of NPs disturbs focus projection $(\approx$ accents can only indicate narrow focus domains).

Against this background, the data discussed in the present paper lend considerable support to the hypothesis that both manner adverbs and resultoriented adverbs have their base position between the subject NP and object NPs for transitive verbs; left of the subject NP for intransitive verbs of coming into existence (erscheinen 'appear') and right of the subject NP for intransitive verbs otherwise (which were not tackled in this paper). (88) shows 
the transitive case. This hypothetical base order will be called AOV (adverb object verb) order in the following.

$$
\mathrm{NP}_{\text {subj }} \text { Adv } \mathrm{NP}_{\text {obj }}\left(\mathrm{NP}_{\text {iobj}}\right) \text { Verb }
$$

Subsequently, $\mathrm{NP}_{\text {obj }}$ can be moved to the left of Adv (if Adv is a manner adverb) or even has to be moved there (if Adv is a result-oriented adverb). If NP is moved, it becomes topical. Luckily though, even for indefinite NPs, there are ways to deal with their topicality that allow for a sentence meaning that will suit in virtually any context - i.e. no strongly visible pragmatic restrictions will arise. Verbs of creation and coming into existence do not support this unobtrusive kind of topicality and consequently offer a good test case to demonstrate that $\mathrm{NP}_{\mathrm{Obj}}$ to the left of Adv are indeed topical.

This position has, however, been seriously challenged in recent work of Frey and Pittner (Frey and Pittner 1998; Frey 2000, this volume). They claim that the German base position for manner adverbs is immediately to the left of the verbal complex and after all nominal arguments. I will abbreviate it as OAV (object adverb verb) order:

$$
\text { Frey and Pittner: } \quad \mathrm{NP}_{\text {subj }} \mathrm{NP}_{\text {obj }}\left(\mathrm{NP}_{\text {iobj }}\right) \text { Adv Verb }
$$

I want to discuss this assumption in some more detail, mainly addressing the article by Frey (this volume). Three tests for base positions are proposed by Frey (2000):

(I) Existential $w h$-phrases in German can only appear in base position.

(II) Wide focus projection indicates that all material is in base position.

(III) Scope reversal arises only under reconstruction (i.e. if a scope bearing element appears in a scrambled position and can return to its base position before interpretation).

Test (II) here will have to be taken with a grain of salt. Frey and Pittner later allow for another reason for wide focus projection, namely so-called integrated constructions (Jacobs 1992, 1993). Let me first review the data that are offered in order to lend support to OAV in the light of tests (I) to (III).

Frey (this volume) presents (90) as evidence in favour of OAV, according to test (I).

(90) Peter will jetzt was konzentriert lesen. Peter wants now s.thing concentratedly read 
If $w h$-phrases have to occur in base position, he argues, then the base position of the object NP (was) is to the left of the adverb (konzentriert). However, consider German examples like (91) which are as well formed as (90) and would support AOV, according to test (I).

(91) a. Alicia hat dann gierig was gegessen.

Alicia has then greedily s.thing eaten

b. Peter hat dann vorsichtig wen gefragt. Peter has then carefully s.one asked

c. Claudia hat demonstrativ was gelesen. Claudia has ostentatiously s.thing read

d. Eberhard zog schüchtern was aus. Eberhard took shyly s.thing off

The result of these findings is (somewhat disappointingly) that either test (I) cannot be trusted or that there are in fact two base positions for manner adverbs.

I will not make use of test (III) because manner adverbs do not exhibit clear scope effects. Frey proposes to use in jeder Weise 'in every way' but I hold it to be unclear what "ways" or "manners" are in play here; after all, the question in welcher Weise can be answered with manner adverbials, subordinated sentences and with instrumental PPs or mental-attitude adjuncts (which both occupy a syntactic class different to manner adverbs, according to Frey (this volume)).

In welcher Weise hat er die Frau umworben?

In which way has he the woman courted?

a. Er hat sie umworben, indem er ihr Blumen auf den Balkon warf. He has her courted by he her flowers onto the balcony threw

b. Er hat die Frau schmierig umworben. He has the woman slimily courted

c. Er hat die Frau mit Liedern und Geschenken umworben. He has the woman with songs and gifts courted (theme?)

d. Er hat die Frau mit einer Balalaika umworben. (instrument) He has the woman with a balalaika courted

e. Er hat die Frau bereitwillig umworben. (mental attitude) He has the woman eagerly courted

Hence we remain with test (II). It has already been mentioned several times in this paper that the word order in (88) allows for wide focus projection, 
and Frey and Pittner do not deny this. This is once more exemplified in (93).

(93) Alicia hat vorsichtig ein Huhn gestreichelt.

Alicia has carefully a chicken stroked

Frey and Pittner offer two counter-arguments. Firstly, they claim that sentences like (93) exhibit "integration" of object NP and verb in the sense of Jacobs (1993). If integration occurs, then a single focus accent is enough to cover the whole integrated domain; and - as Frey and Pittner (1998) propose - the integrated material forms a verbal complex. A test for this is whether or not the verb alone can be moved to sentence-initial position. Indeed, sentences like those in (94) pass this second test for integration as well as the focussing test. ${ }^{15}$

(94) a. ???Gestreichelt hat Alicia vorsichtig ein Huhn. stroked has Alicia carefully a chicken

b. ???Gelesen hat Cecile aufmerksam ein Buch. read has Cecile carefully a book

Yet both focus projection and (possibly) the verb's resistance to front without its object NP could also be explained by the AOV base position. Hence, we will need evidence in favour of undisturbed focus projection with the OAV word order. Frey offers (95) as a second argument in favour of OAV base position:

(95) Peter hat den Artikel sorgfältig gelesen.

Peter has the article carefully read

This is, however, a problematic example. The pragmatic behaviour of definites was discussed in Section 5 and we saw that the definite NP den Artikel in this position has to be topical, i.e. refer to a known object in the common discourse universe. But then imagine the natural flow of a conversation about Peter: If we already know that there is Peter and that there is this article, then the questions What happened then? (a common test for wide focus) and What did Peter do to the article? (a common test for narrow focus) are interchangeable. In other words: the question What happened then? is not a very reliable test for wide focus if we are dealing with known agents and objects. Tellingly, these matters change once we use indefinite NPs: 
Was geschah dann?

'What happened then?'

a. *Peter hat ein Buch sorgfältig gelesen.

Peter has a book carefully read

(narrow focus, or the described generic interpretation of indefinite)

b. Peter hat ein Buch sorgfältig gelesen.

(ok, in-group reading cf. Section 6)

c. Peter hat sorgfältig ein Buch gelesen.

Peter has carefully a book read

(ok, due to base position and/or integration)

The data in (96) seriously challenge the OAV word order proposed in (89).

Let me finally elaborate Frey's integration hypothesis for (89) and (96c).

It emerges that it will face problems once we extend it to resultative adverbs and verbs of creation. It was shown in Section 2 that resultative adverbs have to stay close to the verb:

(97) a. *Berenike hat üppig den Baum dekoriert.

Berenike has lavishly the tree decorated

b. Berenike hat den Baum üppig dekoriert.

Berenike has the tree lavishly decorated

As integration is viewed as a relation between verb and argument NPs, (97b), in which the resultative adverb must intervene, should indicate that it is forbidden to integrate den Baum and dekoriert. However, sentences like (98) falsify this expectation:

(98) Berenike hat vorsichtig den Baum dekoriert.

Berenike has carefully the tree decorated

If the possibility of integration were driven by the semantic nature of verb, object, and the way they relate then we should expect that den Baum dekorieren can form an integrated unit no matter what kind of adverb comes next.

In response to this objection, Frey might claim that the relation between verb and resultative adverb differs from that between verb and manner adverb. The resultative adverb, in some sense, is still oriented towards the referent of the object NP and, in this sense, it might change the thematic structure of the verb. ${ }^{16}$ Common responsibility for the overall thematic structure of the predicate is - following Frey and Jacobs - another licenser 
for integration. Perhaps, NP + verb cannot integrate because resultative adverb and verb are inclined to integrate to an even higher degree?

But again, this cannot be the case because resultative adverb and verb do not form a common focus domain.

(99) a. Berenike hat den Baum üppig dekoriert.

(narrow focus)

b. Berenike hat den Baum üppig dekoriert. (narrow focus)

c. Berenike hat den Baum üppig dekoriert. (narrow focus)

d. Berenike hat einen Baum üppig dekoriert.

(NP topical, outside focus)

e. Berenike hat einen Baum üppig dekoriert. (still no straight wide focus, as proved in Section 6)

Finally, the behaviour of verbs of creation and resultative adverbs would certainly appear odd under Frey's proposal. Verbs of creation and their objects apparently can "integrate":

(100) Desdemona hat konzentriert ein Kleid entworfen. (wide focus) Desdemona has concentratedly a dress designed

However, they resist integration once a resultative adverb is in play, although this would be the one and only chance for the indefinite NP to enter the sentence at all (in an existential reading as in (100))!

(101) *Desdemona hat hauteng ein Kleid entworfen. Desdemona has tightly a dress designed

Let me summarize the pros and cons for the two word order hypotheses in (88) (AOV: universally Adv - Obj - Verb) and (89) (OAV: Obj - Adv Verb). It emerges that neither one is cost-free: Where Frey has to diagnose that integration is blocked, the AOV hypothesis forces us to claim that resultatives force NPs to move. But while OAV will predict that NPs can have base positions so unusual that existential indefinites cannot survive there, AOV keeps the picture that indefinites are fine in all base positions but sometimes may not stay there - below resultatives, in subject position of individual-level predicates, in object position of attitude verbs like love or hate. Moreover, if they are moved, they uniformly become topical.

I will leave it to the readers to decide whether topical base positions or obligatory movement would make the better choice. I hope to have contributed to the debate by drawing attention to the syntactic behaviour of resultative adverbs, and to the topical nature of pre-adverbial NPs. The paper also offers a moral to the investigating researcher in pragmatics: Not all sen- 
tences that can answer the question What happened? necessarily are out-ofthe-blue. There are subtle topics.

\section{Appendix: Referential and denotational topics}

The range of topical NPs that played a role in the paper is treated by two authors, Büring (1996) and Jäger (1996a, b) which I will take as the referential poles in the discussion, thereby ignoring a wealth of other literature for the sake of a brief exposition, appropriate for an Appendix.

Sentences (102) to (105) set the range of data to be treated, accents are given. The / symbol marks rise accents, $\backslash$ indicates a fall.

(102) Ein Schwede hat Schweiß|füße.

(103) Ein/Schwede hatte Schweiß|füße.

(104) Ein blonder/Schwede hatte Schweiß/füße.

(105) Ein Schwede/ hatte Schweiß|füße. 'A (blonde) Swede had (has) sweaty feet'

The accents on Schweissfüsse turn out to be focus accents upon brief reflection, and the subject NPs are topical in all cases (here both Jäger and Büring agree).

Büring's account treats the rise accent / as topical accent and offers a semantic interpretation $[[.]]^{\mathrm{T}}$ that resembles focus semantics but moreover links the content of the sentence (and its alternatives) to a salient topical question. Importantly, the alternatives that play a role in $[[\alpha]]^{\mathrm{T}}$ are alternative meanings of the same logical type as the denotation of $\alpha$ (this is as in focus semantics). I will call this "denotational topic". This will lead us to consider alternative predicates in (104), alternative quantifiers in (105) and alternative determiners in (103). These last alternatives are appropriate only in limited cases and certainly not here, and hence Büring's account is tailored for (104) and (105) while missing (many) cases like (103).

Jäger assumes that the referential argument of a topical NP has to be a known object $p$ in the discourse context. The / accent within topic marks focussed material within topic, i.e. information that is new about the known object $p$. The Swede $p$ must hence be known (as part of a set of known individuals) in all cases (102)(105), but is known as a Swede in (103), known as a Swede but newly asserted to be blond in (104), and known as a person but newly asserted to be a Swede in (105). I will call this notion of topic "referential topic". - In contrast to Jäger, I will claim that the accent / in (103) does not signal new information but simply serves the job of signalling that the noun Schwede contributes old material (in the spirit of Schwarzschild (1999)). Otherwise we would predict that the narrow focus-in-topic in (104) implies that the cardinality information ein 'one' is known information which is not correct. $^{17}$

Not much has been said with respect to (102) so far, and I will follow common wisdom here in assuming that completely unfocussed indefinite NPs are completely 
topical, hence generic, and that generic sentences can generally associate with focus (as Rooth (1995), among others, proposes).

I think that the distinction between denotational topics and referential topics lies at the heart of a proper understanding of the full range of (103) to (105). Büring's account allows remarkably strong predictions about the kinds of contexts that support certain sentences (including the famous Scope Inversion Conspiracy (Büring 1997) but fails in (103) and possibly even (105). ${ }^{18}$ Jäger, on the other hand, does not have much to say about the focus following the topic. While remarking that "topics can associate with focus" in a vague way, he does not explain why they have to associate with focus and neither how the overall construction relates to a discourse topic (topical question).

A full account of referential topicality will hence have to exhibit at least the following features (remember that Understood Entities are objects that are accessible to all anaphoric constructions apart from pronouns; see Section 5):

$[[\alpha]]^{\mathrm{refT}}=$ the referential argument $p$ of $[[\alpha]]$ has to be an old Understood Entity.

Parts of old Understood Entities are also old Understood Entities.

(Expressions that do not introduce a referential argument cannot be referential topics, only denotational topics.)

$\left[\left[[\beta \gamma]^{\mathrm{F}} \delta\right]\right]^{\mathrm{refT}}=$ "focussed material within refT contributes new information about old $p . "$

Referential topics associate with focus to create the "referential topical question". The referential topical question basically equals the non-focal non-topical material in the sentence where we lambda-abstract over the focal argument and lambdaabstract over discourse referents over the referential topical argument. Let me give an impressionistic example:

(106) $[\text { Eine Frau/ }]^{\mathrm{refT}}$ hat $[\text { eine Lampe }]^{\mathrm{F}}$ gekauft. a woman has a lamp bought Topical question: "Who amongst the set of known discourse entities $\mathrm{P}$ of which $p=$ a woman is part - who of these bought what?"

$\lambda \mathrm{p} \lambda \mathrm{x} .(\mathrm{p}<\mathrm{P} \& \exists \mathrm{e}($ buy $(\mathrm{p}, \mathrm{x}, \mathrm{e})))$

The case contrasts with Büring's denotational topical questions like the one in example (107) below. Let me stress the fact that the pure intonation pattern will not tell anything about the kind of topicality that is in play. It has to be derived from other factors (like the availability of a referential argument and speaker's interests).

(107) $[\text { Eine Frau/ }]^{\mathrm{denT}}$ hat $[\text { eine Lampe }]^{\mathrm{F}}$ gekauft. Topical question: "Who bought what?"

$\lambda y \lambda x .(\exists e($ buy $(y, x, e)))$ 
The formula in (106) will evidently only be defined in a framework that allows for lambda-abstraction over discourse referents; Muskens (1996) offers this possibility. Intuitively, the topical question in (106) is concerned with individuals that we already know in context, while (107) asks for customers in general without referring to any given group of customers. Note that (107) cannot be restricted to equal (106) even if we allow for further silent predicates that restrict the variable $y$ : Without reference to discourse referents, we will not be able to ensure that $y$ is instantiated with those individuals we had been talking about already.

I will not offer a full elaboration of $[[.]]^{\text {refT }}$ here; this task would require a paper in its own right. Let me finally give another example where the difference between referential topicality and denotational referentiality is highlighted, and an explanation of why created objects are bad referential topics if the focus concerns the respective act of creation.

(108) [Drei/ Aufgaben $]^{\mathrm{den} T}$ hat er gelöst.

(109) [Drei/Aufgaben $]^{\text {refT }}$ hat er gelöst.

Three problems has he solved

The first sentence will refer to the topical question For which quantifier $q$ is it true that he solved $q$ problems? It might arise in a context where candidates have to solve a certain minimum of problems in order to pass the exam but where all problems count as equal.

The second interpretation refers to the problems the candidate actually did solve. The second, but not the first, interpretation allows us to pick up the solved questions with a pronoun: ... and they were fairly tricky, too. The second, but not the first, interpretation determines the meaning of die anderen 'the others' as in ... die anderen hat er nicht einmal probiert 'but the other ones, he did not even look at'.

The first interpretation, but not the second one, allows the speaker to continue: ... aber vier/ Aufgaben hat er nicht gelöst, also kriegt er kein "sehr gut" "but he didn't solve four problems, hence he will not get an A'. In interpretation one, three solved and four unsolved problems will not imply that there were seven problems altogether. In interpretation two, the two sentences together will necessitate that the candidate had seven problems to solve.

What will happen in a sentence like (110) (= sentence (79)) where referential topic meets a focussed verb of creation?

\section{(110) Alicia hat [eine Taschenlampe/ $]^{\mathrm{refT}}\left[\right.$ ökonomisch konstruiert] ${ }^{\mathrm{F}}$}

refT requires that the referential argument $p$ of "a torch" is part of a known group individual $P$ available in the discourse context. The referential topical question is What happened to elements of $P$ ? In a normal narrative, the reference time $\mathrm{R}$ is located at a point where $P$ is a known object at the non-modal level of the narrative. Hence $P$ exists at the beginning of $\mathrm{R}$. The verb of creation 'construct economically', however, asserts that $p$ is constructed at reference time $\mathrm{R}$ (within or around 
depending on aspect, see Klein (1994) and Hinrichs (1985). Adopting the semantics of verbs of creation in von Stechow (2001) will imply that $p$ only exists after the event time, i.e. not at the beginning of reference time R. This contradicts the common background information above, that $P$ as a whole (and hence in all its parts) did exist at the beginning of $\mathrm{R}$. Which shows the hearer that she has accommodated incoherent background information and hence failed to spell out the conversational maxim of quality: "Assume that the speaker intends to tell the truth."

\section{Notes}

1. I would have preferred "How to create things in a certain way" for a title, but this one covers about any key noun that will be used in the article. The paper was written as part of SFB 471 Wandel und Variation im Lexikon, and although it does not specifically deal with variation, the contents were shaped by the lively and inspiring environment at Konstanz. Specifically, I want to thank Willi Geuder, Renate Musan and Arnim von Stechow for useful discussions.

2. I will use "manner adverb" and "result-oriented adverb" in this introduction without offering a definition, relying on the reader's intuitive understanding of the terms. Section 2 will be devoted to clarifying this terminology. I will mostly use German verb-final sentences in order to avoid further complications that arise by deriving V2.

3. Originally, Jackendoff (1975) used the term "subject-oriented adverbs" to refer to those adverbs that always predicate over the grammatical subject of the sentence (no matter what thematic role it maintains) in contrast to those adverbs that invariably orient towards the agent of an event and cannot refer to any other participant. Frey (this volume) discusses the case under the label "mental-attitude adverb". I will follow the terminology of Geuder (2000) at this point.

4. This argument is not discussed in Geuder (2000).

5. Tastes of German linguists differ as to how bad they find definite NPs that are "unduly far to the right". Some scholars accept definites in virtually any position while others tend to star sentences quickly. Ultimately, these tendencies correlate with the ease with which less-than-out-of-the-blue contexts are accepted as "normal" by speakers. In the present section, I will follow a liberal strategy to accept definites while the next section will review Jäger's more refined picture as to which NPs presuppose what kind of discourse universe.

6. Note that expressively can sometimes also be a manner adverb, e.g. in dancing expressively. Eventually, the range of possible readings is determined by the combination of verb + adverb and only few adverbs are "manner" or "result" perse.

7. Let me warn the reader against taking the following boxes as Jäger's full formal framework which is actually more in the spirit of Groenendijk and Stokhof's Dynamic Intensional Logic than Kamp and Reyle's Discourse Represen- 
tation Theory. For details, the original thesis (Jäger 1996b) should be consulted.

8. Jäger's work is concerned with the theme/rheme distinction, also sometimes discussed as topic/focus, or as the distinction between thetic and categoric sentences. This distinction is not immediately the same as the notion of focus that was discussed in the literature on association with focus by Rooth, Krifka, Büring, Jacobs etc. It is easy to see this by noting, for example, that even definite NPs that refer to Understood Entities (and should hence be "topical") can still be focussed in the latter sense, as in:

Joe bought a car which is entirely red. Even [the steering wheel $]_{\text {fous }}$ is red.

9. Let me make it clear that I do not intend to defend this classification as the ultima ratio in the interpretation of noun phrases. Still, Jäger's treatment - in spite of possible shortcomings and simplifications - is one of the most elaborate and differentiated accounts available.

10. Cf. Ladusaw (1994), Jäger (1992), Eckardt (1996).

11. Jäger calls both readings in (66) and (67) partitive readings. This would, however, be misleading for the purposes of the paper. Let me stress that specificity is orthogonal to the issues that I discuss here. In particular, an indefinite can have an in-group reading although the speaker is not acquainted with the referent, and an indefinite can receive a specific interpretation ("a certain") without necessarily being one of a known group.

12. In order to be complete with respect to the readings of at least the core examples in this paper, I have to add the following readings for (70a): The accented material can be understood as a contrastive focus. If so, then the respective sentence will contrast with a similar sentence that differs form (70a) in the focussed material. Importantly, the contrasted sentence will get the same reading as the original sentence had, and the original sentence will have received its reading according to one of the possibilities that are discussed in the set in (70). Similar possibilities exist for (70b) and (70c).

13. This is not to say that contradictory sentences are always ungrammatical which they certainly are not. Yet the hearer allows for accommodation only in order to rescue what would otherwise be an incoherent discourse, and $\mathrm{s} / \mathrm{he}$ does so because she assumes that the speaker will have something rational to say. If the accommodation leads to contradictions with the literal content of the sentence then it must be a wrong accommodation: It was made on the assumption of a rational speaker and the result of the process contradicts this very assumption.

14. ... or in-group. Diesing herself did not pay attention to in-group readings, but this gap has been closed by Jäger (1996a, b) since.

15. The sentences are borderline cases between "need a very odd context" and "are bad indeed". I will for the sake of the argument behave as if they were really bad.

16. This observation offers an attractive basis to integrate result adverbs in the general programme of Ernst (this volume) according to which all adverbs find their syntactic positions in dependence on their semantic properties - specifi- 
cally, the NPs they predicate over. If the result-oriented adverb predicates over the referent of the object NP, then it will have to have scope lower than this $\mathrm{NP}$, hence to its right (in German, and, surprisingly, in English as well ...). I will not be able to elaborate these ideas here.

17. As promised, I am very brief here. The reader might want to check this prediction by going through the original proposal by Jäger and testing more cases with higher cardinals, like five blonde/ Swedes had stinky feet. - Even if we know that there are Swedes around, this sentence does not require contexts where the hearer is certain that the number of Swedes exceeds five.

18. I think that (105) should be continued ... a Dane had a blister on his toe, and another Swede had a corn on the foot. Yet, Büring would assume that (105) exhausts the range of relevant true propositions that we can make with $A$ Swede had ... . Once more, the problem is that he cannot account for the fact that the same NP ein Schwede can very well refer to different Swedes.

\section{References}

Büring, Daniel

1994 Topic. In Focus and Natural Language Processing, Vol. II, Peter Bosch and Rob van der Sandt (eds.) Heidelberg: Working Papers of the Institute of Logic and Language. Reprinted in Focus, Peter Bosch and Rob van der Sandt (eds.), 142-165. Cambridge: Cambridge University Press.

1996 The 56th Street Bridge Accent. London: Routledge.

1997 The great scope inversion conspiracy. Linguistics and Philosophy 20: 175-194.

Chomsky, Noam, and Morris Halle

1968 The Sound Pattern of English. New York: Harper \& Row.

Cinque, Giuliemo

1993 A null theory of phrase and compound stress. Linguistic Inquiry 24: 239-297.

Diesing, Molly

1990 The syntactic roots of semantic partition. Ph.D. dissertation, University of Massachusetts, Amherst.

1992 Indefinites. Cambridge, Massachusetts: MIT Press.

Dowty, David

1979 Word Meaning and Montague Grammar. Dordrecht: Reidel.

Eckardt, Regine

1996 Intonation and Predication. (Arbeitspapier 77 des Sonderforschungsbereichs 340.) University of Tübingen and Stuttgart.

1998 Events, Adverbs, and Other Things. Tübingen: Niemeyer Verlag.

1999 Focus with nominal quantifiers. In Focus, Peter Bosch and Rob van der Sandt (eds.), 166-186. Cambridge: Cambridge University Press. 
Enç, Mürvet

1991 The semantics of specificity. Linguistic Inquiry 22(1): 1-25.

Ernst, Thomas

2003 Semantic features and the distribution of adverbs. In this volume.

Fintel, Kai von

1994 Restrictions on quantifier domains. Ph.D. dissertation, MIT.

Frey, Werner

2000 Syntactic requirements on adjuncts. In Approaching the Grammar of Adjuncts, Ewald Lang, Cathrine Fabricius-Hansen, and Claudia Maienborn (eds.), 107-134. (ZAS Papers in Linguistics 17.) Berlin: Zentrum für Allgemeine Sprachwissenschaft.

2003 Syntactic conditions on adjunct classes. In this volume.

Frey, Werner, and Karin Pittner

1998 Zur Positionierung der Adverbiale im deutschen Mittelfeld. Linguistische Berichte 176: 489-534.

Geilfuß, Jochen

1992 Nominal quantifiers in association with focus. ConSole I Proceedings, 138-147. Amsterdam: SoLe Publications.

Geilfuß-Wolfgang, Jochen

1996 Über gewisse Fälle von Assoziation mit Fokus. Tübingen: Niemeyer.

Geuder, Wilhelm

2000 Oriented adverbs. Issues in the lexical semantics of event adverbs. Ph.D. dissertation, University of Tübingen.

Groenendijk, Jeroen, and Martin Stokhof

1991 Dynamic predicate logic. Linguistics and Philosophy 14(1): 39-100.

Groenendijk, Jeroen, Martin Stokhof, and Frank Veltman

1994 Update Semantics for Modal Predicate Logic. Technical Report, ILLC, University of Amsterdam.

Gussenhoven, Carlos

1983 Focus, mode, and the nucleus. Journal of Linguistics 19: 377-417.

Hinrichs, Erhard

1985 A compositional semantics for aktionsarten and NP reference in English. Ph.D. dissertation, Ohio State University.

Höhle, Tilman N.

1982 Explikationen für 'normale Betonung' und 'normale Wortstellung'. In Satzglieder im Deutschen, W. Abraham (ed.), 75-153. Tübingen: Niemeyer.

Hoop, Helen de

1992 Case configuration and noun phrase interpretation. Ph.D. dissertation, University of Groningen.

2000 Optional scrambling and interpretation. In Interface Strategies, H. Bennis, M. Everaert, and E. Reuland (eds.), 153-168. KNAW, Amsterdam. 
Jackendoff, Ray

1975 Semantic Interpretation in Generative Grammar. Cambridge, MA: MIT Press.

Jacobs, Joachim

1983 Fokus und Skalen. Zur Syntax und Semantik der Gradpartikeln im Deutschen. Tübingen: Niemeyer Verlag.

1992 Integration. (Arbeitsbericht Nr. 13, SFB 282 "Theorie des Lexikons".) Universities of Düsseldorf and Wuppertal.

1993 Integration. In Wortstellung und Informationsstruktur, Marga Reis (ed.), 63-117. Tübingen: Niemeyer Verlag.

Jäger, Gerhard

1992 Diskursverknüpfung und der Stadien-/Individuenkonstrast. MA thesis, University of Leipzig.

1996a The stage/individual level contrast revisited. Proceedings of WCCFL 15: 225-240. CSLI Stanford.

1996b Topics in dynamic semantics. Ph.D. dissertation, Humboldt University Berlin. In print: University of München, CIS-Bericht 96-92.

Klein, Wolfgang

1994 Time in Language. London: Routledge.

Krämer, Irene

2000 Interpreting indefinites. An experimental study of children's language comprehension. Ph.D. dissertation, Utrecht/Nijmegen.

Kratzer, Angelika

1989/1995 Stage-Level and Individual-Level Predicates. In Genericity in Natural Language, M. Krifka (ed.) (Proceedings of the 1988 Tübingen Conference, SNS-Bericht Nr. 42.) Tübingen University. Published in The Generic Book, Greg Carlson and F. Jeff Pelletier (eds.), 125-176. Chicago: Chicago University Press.

Krifka, Manfred

1991 A compositional semantics for multiple focus constructions. In Proceedings of the 1991 SALT Conference, 127-158. Dept. of Modern Languages and Literatures, Cornell University.

Kuroda, Sige-Yuki

1972 The categorical and the thetic judgement. Foundations of Language 9: 153-185.

Ladusaw, William

1994 Thetic and categorical, stage and individual, weak and strong. Proceedings of the 1994 SALT IV Conference, 220-229. Dept. of Modern Languages and Literatures, Cornell University.

Muskens, Reinhard

1996 Combining Montague semantics and discourse representation. Linguistics and Philosophy 19: 143-186.

Parsons, Terence

1990 Events in the Semantics of English. Cambridge, MA: MIT Press. 
Reinhart, Tanya

1981 Pragmatics and linguistics. An analysis of sentence topics. Philosophica 27: 53-94.

2000 Strategies of anaphora resolution. In Interface Strategies, Hans Bennis, M. Everaert, and E. Reuland (eds.), 295-324. North Holland, Amsterdam.

Rooth, Mats Edward

1985 Association with focus. Ph.D. dissertation, University of Massachusetts at Amherst.

1992 A theory of focus interpretation. Natural Language Semantics 1: 75116.

1995 Indefinites, adverbs of quantification, and focus semantics. In The Generic Book, Greg Carlson and Francis Jeffrey Pelletier (eds.), 265-299. Chicago: Chicago University Press.

Sasse, Hans-Jürgen

1987 The thetic/categoric distinction revisited. Linguistics 25: 511-580.

Schwarzschild, Roger

1999 GIVENness, AvoidF and other constraints on the placement of accent. Natural language semantics 7: 141-178.

Stechow, Arnim von

2001 Temporally opaque arguments. In Semantic Interfaces: Studies Offered to Andrea Bonomi on the Occasion of his Sixtieth Birthday, Carlo Cechetto, Gennaro Chierchia, and Maria Teresa Guasti (eds.), 278-319. Stanford: CSLI Publications.

Zimmermann, Ede Thomas

1993 On the proper treatment of opacity in certain verbs. Natural Language Semantics 1: 149-179.

Zucchi, Alessandro

1999 Incomplete events, intensionality and imperfectivity. Natural Language Semantics 7: 179-215. 